$\begin{array}{llllllllll}M & \mathbb{A} & \text { T } & \text { E } & \text { R } & \text { I } & \bar{A} & \text { L } & \text { S }\end{array}$

Roman Jurkowski

University of Warmia and Mazury in Olsztyn

\title{
Is Every Pole a Catholic? - the Borderland Quandaries of Nationality and Religion Faced by Russian Bureaucracy in a 1910 Ministry of Internal Affairs Document
}

Zarys treści: Przedstawiony tekst źródłowy jest dokumentem pokazującym bezradność carskiej biurokracji wobec skomplikowanych stosunków narodowościowo-wyznaniowych występujących w zachodnich guberniach Rosji, dawniej stanowiących ziemie Wielkiego Księstwa Litewskiego. Dążąc do tego, aby po powstaniu styczniowym skutecznie ograniczyć polskich ziemian w zakresie praw do władania majątkami ziemskimi, władze rosyjskie zmuszone były najpierw określić, kogo uznawały za „osobę polskiego pochodzenia” i jakie cechy wyróżniały takie osoby spośród innych właścicieli ziemskich. Referat zatytułowany: „Kogo należy uważać za «osobę polskiego pochodzenia»", przygotowany w 1910 r. przez naczelnika VII oddziału Departamentu Spraw Ogólnych Ministerstwa Spraw Wewnętrznych, jest świadectwem, że przez ponad pół wieku od upadku powstania władzom rosyjskim nie udało się precyzyjnie określić przedmiotu swoich działań represyjnych.

Outline of content: The source text is a document that demonstrates the perplexity of Russian bureaucracy when confronted with the complex interplay of nationality and creed in Russia's western guberniyas, formerly part of the Grand Duchy of Lithuania. As following the January Uprising Russian authorities intended to effectively curtail the rights of Polish landed gentry to administer their estates, they were first forced to define who could be considered a "person of Polish origin" and what features made such persons distinct from other landowners. A report entitled "Who should be considered a 'person of Polish origin", drafted in 1910 by the head of the 7th division of the Department of General Affairs at the Ministry of Internal Affairs, bears witness to the fact that, for more than fifty years after the uprising had been suppressed, Russian authorities failed to precisely define the object of their repressive measures.

Słowa kluczowe: ziemstwa zachodnie, Ministerstwo Spraw Wewnętrznych Rosji, definicja narodowości, polityka dyskryminacyjna Rosji

Keywords: Western zemstva, Ministry of Internal Affairs of Russia, definition of nationality, Russian policy of discrimination 
While the January Uprising was still raging within the former Grand Duchy of Lithuania, it was an easy thing for Mikhail Muravyov and the military and civil authorities subordinated to him to pick out individuals to prosecute for participation in the insurrection. All "political criminals", or those caught in arms or merely suspected of siding with the rebels, had to be duly punished, whether by death, transportation, prison or forfeiture or seizure of estates. But the intention of Muravyov and the high-ranking Petersburg officialdom that backed him was not limited to capturing and sentencing those who actively opposed the Russian Empire. These makeshift penalties were merely an onset of the entire system of repression introduced in Russia's western guberniyas, ostensibly designed to punish the myatezhniks [rebels], but actually having more far-fetched objectives. The issue at stake was to permanently stamp out the influence of Polish landed gentry on the political, economic and social life of the eastern lands of former Poland. Limiting the economic and social role of Polish landed gentry was the prelude to expediting the Russification of Lithuanians, Belorussians and Ukrainians, thereby rapidly merging the former GDL lands into the vast Romanov state. Yet when applying collective responsibility for a "rebellion", especially one long suppressed, it was necessary to squarely define who was a "rebel". In other words, for long-term repressive measures to be implemented, a legal system had first to be established to define those who were to be repressed. This is the root cause of the term 'person of Polish origin', which was used in the legal and official language of Russian administration from the January Uprising until the last days of the tsarist regime. Even after dozens of years had passed since the uprising, this term, first used in a legal instrument from March 1864, was repeatedly used to further Russian national policy in the Empire's western guberniyas. A few years before the outbreak of the First World War, the issue of setting Poles apart from the mass of individuals living in the nine western guberniyas resurfaced, as plans were being made to introduce self-government (zemstvo) institutions in six of them.

The problems related to extending the zemstvo system to the Minsk, Mogilev, Vitebsk, Kiev, Podolia and Volhynia guberniyas from 1901 to 1911 are relatively well discussed in Polish historiography, primarily thanks to the excellent biography of Pyotr Stolypin written by Ludwik Bazylow. ${ }^{1}$ The question was also taken up by Paweł Wieczorkiewicz in a long article published in the Festschrift in honour of Bazylow. ${ }^{2}$ Thanks to extensive materials preserved at the Russian State Historic Archive in Petersburg, we can now quite precisely outline the entire preparatory and decision-making process followed by Russian government institutions at various levels in relation to providing these guberniyas with zemstvos,

\footnotetext{
${ }^{1}$ L. Bazylow, Ostatnie lata Rosji carskiej. Rządy Stołypina, Warszawa, 1972.

2 P. Wieczorkiewicz, "Stołypin, Polacy i ziemstwa zachodnie", in: Słowiańszczyzna i dzieje powszechne. Studia ofiarowane Profesorowi Ludwikowi Bazylowowi w siedemdziesiata rocznice Jego urodzin, eds. L. Jaśkiewicz et al., Warszawa, 1985, pp. 125-153.
} 
however discussing this complex procedure in a comprehensive manner would require a separate monograph.

The essential issue that Russian authorities had to tackle when introducing zemstvos in selected western guberniyas was to draft such rules of choosing zemstvo members as would prevent Polish landed gentry, much numerous in uyezds and therefore in zemstvos than their Russian counterparts, from being elected. This required a radical transformation of zemstvo electoral law to partition voters according to national criteria. Once this partition was made, the next step was to adroitly falsify the statistics and introduce a complex method of calculating the number of Poles authorised to elect zemstvo members in order to "demonstrate" that Polish voters are less numerous than Russian ones. This was in contrast to other guberniyas, where the elections were based on a curial system that used social standing and not nationality. ${ }^{3}$ All this elaborate and complex structure of electing zemstvo members that originated at the Ministry of Internal Affairs was designed to artificially reduce the number of members of Polish origin, yet acted to pervert the very essence of the zemstvo as a self-government body. This effect is applicable both to the original zemstvo structure from 1864 and the already severely limited variant from 1890. The fact that the new zemstvos would not reflect the principles of how local governments should be elected and operate did not matter for MIA officials who devised ways to "reduce" the number of Polish landed gentry in these guberniyas.

Piotr Stolypin, the prime minister whose idea was to extend the zemstvo structure to the six western guberniyas, ${ }^{4}$ was motivated not just by the intention to reduce the influence of Poles on zemstvo activities but also to achieve a nationwide political objective. His design was to exclude Western Krai Poles from among the elected members of the State Council, as zemstvos in those guberniyas that had them were given the right to elect members of the upper house of the Russian parliament. Therefore, once zemstvos were introduced, the so-called assemblies of nobility formerly held in the nine western guberniyas ceased. In 1906, 1909 and 1910 these assemblies elected only Poles to the State Council due to their numerical superiority.

To devise the entire complex system of separate calculations for each uyezd in the six guberniyas and "prove" that the number of Polish landed gentry did not exceed the number of their Russian counterparts, Russian authorities had first to define who should be considered a Pole - not an easy matter when dealing with the former Grand Duchy of Lithuania population that showed strong national and religious heterogeneity. Adding to this the budding development

\footnotetext{
${ }^{3}$ As Russian landed gentry predominated in Russian guberniyas, the officials thought it obvious that others should follow suit.

${ }^{4}$ At the very start of the reform process, it was decided to exclude the Vilna, Grodno and Kovno guberniyas because the number of Polish landed gentry there was so large that any duplicity in statistics would be perfectly obvious and harm rather than help the government.
} 
of national identity among Lithuanians, Belorussians and Ukrainians and the peculiar "native" national and territorial identification among some landed gentry, the document discussed here shows that the Russian administration failed to find a solution.

One of such attempts to define who should be considered a "person of Polish origin" in connection with plans to introduce zemstvos in six western guberniyas was a report drafted by Konstantin Strolman, head of the 7th division of the Department of General Affairs at the Ministry of Internal Affairs. ${ }^{5}$ Strolman's division was charged with designing state policy towards other nationalities living in the western fringes of the Empire. It dealt with, among others, strengthening Russian landholdings in the nine western guberniyas, countering the rising popularity of local languages, all matters related to Russian interests in Western Krai areas, and the issues of protecting national borders and the status of border regions. ${ }^{6}$ For these reasons the report was included in the extensive collection of documents submitted by the MIA to the State Duma chancellery which examined government bills that, once approved by the Duma, were sent to the State Council. ${ }^{7}$

The document discussed below, preserved in the collections of the Russian State Historical Archive in St. Petersburg, has the nature of a historical and legal analysis. Its purport is inseparably bound with the repressions of Polish landed

${ }^{5}$ Konstantin Alexeevich Strolman (1861-1941) was born into a family with Swedish, German and Russian roots. A graduate of Petersburg University, on 13 February 1891 he was employed at the Department of General Affairs of the Ministry of Internal Affairs. With the reorganization of special divisions of the Department, on 1 January 1903, as a fifth grade official for special orders subordinated to the minister of internal affairs, he was tasked with organizing the new 7th division of the Department of General Affairs which he managed until 1917. He died during the Leningrad blockade. He was the younger brother of Sergei Strolman (1854-1937), a mining engineer corps general and the director of Perm Artillery Works since 1897.

6 The Russian State Historical Archive in Sankt Petersburg (hereafter: RGIA), coll. 1284 (Департамент общих дел МВД), series 183, sec. 34, fol. 56. For the special role of the Department of the General Affairs of the MIA during the terms of Dimitry Sipyagin and Vyacheslav von Plehve, see Н.Г. Базина, “Возникновение национально-политической части Департамента общих дел Министерства внутренних дел”, Известия Российского государственного педагогического университета им. А.И. Гериена, 2006, no. 22, vol. 4, p. 17-23.

7 On 4 March 1911, the State Council rejected the western zemstvos project, which proved to be the greatest political debacle in Stolypin's career. While he managed to induce Nicholas II to issue a decree suspending the deliberations of both houses for three days and on 14 March 1911, under section 87 of the Fundamental Laws, a zemstvo statute for the six western guberniyas was promulgated, but according to the law, an imperial decree issued under section 87 had to be subsequently ratified by the State Duma and State Council. This, however, never happened, and therefore the 1913 elections to the State Council should, strictly according to the letter of the law, have been organized under the previous electoral system. Yet the minister of internal affairs Mikhail Maklakov disregarded the legal intricacies and ordered that elections in the six guberniyas should be held by the so-called Stolypin land assemblies established pursuant to the 14 March 1911 decree. The assemblies did not elect any Polish members to the State Council. 
gentry following the January Uprising. It was then that the "persons of Polish origin" term appeared as the authorities needed to divide landowners into Poles and non-Poles against a background of penal rights that limited the capability of Polish landed gentry to dispose of their own estates. As evidenced by the document, both in 1910 and until the end of the tsarist regime this term was not made precise or defined in law. In practice, this meant that the decisions on who was a "person of Polish origin" were left to the discretion of governors and governors-general. The document, however, bears witness not only to huge terminological and legal difficulties faced by the Russian bureaucratic machine in Lithuanian, Belorussian and Ukrainian lands. It also shows how complex were (and still are) the issues concerning defining the criteria of national identity (especially in the Borderlands at the turn of the 19th and 20th century) and how they evade being systematically arranged and logically defined.

The A4 typescript of several pages has been conformed to modern Russian orthography, translated by the author and supplied with footnotes. ${ }^{8}$

\section{Доклад начальника VII отделения Департамента общих дел Министерства внутренних дел, статского советника Строльмана по вопросу о том кого следует считать „лицом польского происхождения”.}

РГИА, ф. 1278 (Канцелярия Государственной Думы) оп. 2, д. 1171 (Об применении положения о земских учреждениях 12 июня 1890 г. к губерниям: Витебской, Волынской, Киевской, Минской, Могилевской и Подольской, 22 I 1910 - 14 III 1911 г.), л. 101-103.

Прежде всего считаю долгом доложить, что в Министерстве внутренних дел не имеется по этому богатых данных. Причиной этого недостатка является то обстоятельство, что ограничительные узаконения касающихся лиц польского происхождения применялись на практике местными властями, которым и приходилось останавливаться на обсуждении настоящего вопроса. Правда, в Министерстве внутренних дел нередко поступали жалобы лиц этой категории на местные власти за применение к ним ограничительных узаконений, но и в этом случае министерству не предоставлялось надобности задумываться над вопросом, что разумеется в понятии „лица польского происхождения”. Так все этого рода узаконения оперались на дискреционную, по объяснению Правительствующего сената, власти генерал-губернаторов и министерству достаточно было не входя в обсуждение дела по существу, доносить правительствующему сенату, что обжалованное распоряжение последовало

${ }^{8}$ I wish to thank Prof. Iwona Anna Ndiaye, $\mathrm{PhD}$, for proofreading and valuable notes on both the original and translated document. 
в пределах дискреционной власти местного начальства и не подлежит рассмотрению Правительствующего сената по существу.

Понятие „лица польского происхождения” есть термин ограничительного законодательства в области национально-политической. Впервые, насколько мне известно, он встречается в Высочайше утвержденном 5 марта 1864 г. Положении о льготах, преимуществах и денежных ссудах предоставляемых при покупке казенных и частных имений в западных губерниях. В ст. 26 этого положения значится: „всем приобретателям имений воспользовавшимся каким-либо из установленных настоящим положением льготами и преимуществами или пособием равно их наследниками и преемниками прав запрещается продавать, закладывать или иным образом передавать те имения лицам польского происхождения и евреям". Такого же рода статья содержится и в Высочайше утвержденной 23 июля 1865 г. Инструкции о порядке продажи казенных земель в западных губерниях лицам русского происхождения [emphasis in the original text] служащим в том крае или желающих там водворится на постоянное жительство. Далее тот же термин содержится в Высочайшем повелении 10 декабря 1865 года, коим воспрещено приобретение лицам польского происхождения имений в Западном крае всяким иным путем кроме наследования по закону. В Высочайше утвержденном в тот же день (т.е. 10 декабря 1865 г.) журнале особой комиссии под председательством Д.Т.С. [действительный тайный советник] князя Гагарина, о мерах к водворению в Западном крае русского элемента, на основании какого журнала и последовал приведенное выше Высочайшее повеление 10 декабря 1865 г. содержится попытка дать общее указания относительно термина „лица польского происхождения”. Под выражением „лица польского происхождения", говорится здесь, нужно понимать, не вообе католиков а только поляков и тех западных уроженцев [emphasis in the original text], которые усвоили себе польскую национальность. Хотя в юридическом отношении выражение это может указаться неточным, но на практике к применении к лицам оно не возбуждало доселе никаких сомнений. Между тем, выражением этим устраняется вполне вопрос о вероисповедании, так как было бы совершенно несправедливо делать различие между владельцами не по политическим, а по религиозным соображениям.

Затем известна попытка министра Государственных имуществ дать определение понятию „лица польского происхождения”. Именно в отзыве к генерал-губернатору Северо-Западного края от 10 декабря 1869 г. за № 22, названный министр сообщил: „В виду изложенного в Высочайше утвержденном 10 декабря 1865 г. журнале коммисии, столь ясного указания на то, что основанием к установлению различия между лицами польского происхождения, коим воспрещено приобретение имений в Западном крае и лицам непольского происхождения, должна служить национальность, а не вероисповедание этих лиц, он, министр Государственных имуществ находит что приня- 
тие лицом польского происхождения православной веры не может служить законным поводом к изятию его из действия закона 10 декабря 1865 г. Если потомки этих лиц, будучи православного исповедания усвоят себе, со временем, русскую национальность, точно также как предки многих нынешних польских помещиков Западного края, бывшие некогда русскими, усвоили себе постепенно польскую национальность после перехода из православия в латинство, то все же, для действительного достижения этой перемены национальности нужно немало времени по прошествии коего лица, эти будучи русскими на самом деле, и окончательно отрешившись от польского языка, перестанут считаться лицами польского происхождения. Но действительная перемена национальности не может быть непосредственным, мгновенним последствием перемены исповедания, а потому, если бы допустить изъятие из постановленных относительного лиц польского происхождения правил в пользу всех тех из числа лиц этих кои приняли православие, то это прямо значило бы установить различие между лицами польского и не польского происхождения, но не по национальности а по вероисповеданию, что было бы совершенно противно духу и буквальному смыслу закона 10 декабря 1865 г., который должен всемирно охраняться от всякого его изменения или ослабления.

В виду сего лица польского происхождения хотя и бы принявшие православие ни в каком случае не могут приобретать казенную поземельную собственность на основании Инструкции 23 июля 1865 г. так как собственность эта „продается для привлечения чиновников русского происхождения на службу в западные губерни и для пощрения их к продолжению там службы, а также в видах содействия другим благонадежным лицам русского же происхождения к постоянному в том крае водворению”. В дальнейшем вопроса этого не приходилось касаться до 1905 г. Тем более что 1 ноября 1886 г. было издано Высочайше утвержденное Положение Комитета Министров, которые предоставило дискреционному усмотрению местных начальств выдавать или не выдавать свидетельства на право приобретения имений в Западном крае „как лицам русского, так и нерусского происхождения”.

Далее, на разъяснении этого-же понятия пришлось остановиться и Комитету Министров, когда последний производил пересмотр действующих постановлений ограничивающих права инородцев и уроженцев отдельных местностей Империи в исполнение пункта 7 Именного Высочайшего Указа 12 декабря 1904 г. о предначертаниях к усовершенствованию государственного порядка, коим повелевалось произвести пересмотр этих постановлений, с тем, чтобы из числа их вперед сохранены были лиш те, которые называются насущными интересами государства и явною пользою русского народа. Именно в Высочайше утвержденном 1 мая 1905 г. особом журнале Комитета Министров по делу о порядке выполнения пункта 7 помянутого указа читаем: „Остановление на вопросе, кому может быть предоставлено 
удостоверять это обстоятельство т.е. принадлежность к лицам польского происхождения, Комитет находит что за неустановлением в законе точных признаков понятия "польское происхождение«, поручить сию обязанность совершающим купчие крепости нотариусам было бы затруднительно. Одни лиш чины местной высшей администрации в лицах генерал-губернатора и губернатора могут решать подобные дела в сущестности характера не юридического а политического и тем более сложные, что среди католиков могут быть также и лица не польского происхождения, которых не следует стеснять в покупке имений. Лишь в их распоряжении имеются средства убедиться в том, не является ли проситель поляком или ополяченым литовцем, которого в сем отношении следует приравнивать к полякам. За названными высшими местными начальствами по прежнему надлежит сохранить также право предъявления в суда исков об уничтожении актов состоявшихся по незаконной сделке".

Высочайшее повеление 1 мая 1905 г. отменило вышеприведенное законоположение 1 ноября 1886 г. и ныне местным начальствам уже не принадлежит дискреционное право выдачи или не выдачи свидетельств на право приобретения имений в Западном крае. В следствие сего поступившую ныне жалобу на распоряжение одного из местных губернских начальников о признании данного лица лицом польского происхождения препровожденную Правительствующим сенатом на заключение Министерства, подлежит рассмотреть по существу. В этих видах Министерство обратилось к генерал-губернаторам и губернаторам Западного края прося их сообщить, с точки зрения наблюдателя местной окраинной жизни, кого следует относить к числу лиц польского происхождения. Все отзывы доставлены, но к сожалению их невозможно было дать в настоящую минуту, так как они находятся в Министерстве Финансов, куда они препровождены в виду поручения Правительствующего Сената представить ему заключение по означенной жалобе, по сношении с Министерством Финансов (дело касалось залога имении в Дворянском банке). Следует однако заметить что и эти отзывы не дают ясного, точного и исчерпывающего определения рассматриваемого понятия. Некоторые отзывы отожествляют польское происхождение с принадлежностю к римско-католической церкви: по этому определению всякий католик есть польяк.

Затем можно привести следующую попытку одного из местных начальников обяснить предлежащий вопрос: „Лицом польского происхождения считается тот, кто родился от польских родителей и сам католик. Принятие им или его родителями православие не изменяет его польской национальности. Лишь происхождение просителя исповедующего православную веру от родителей, рожденных в православию может считаться достаточным основанием к признанию просителья лицом непольского происхождения". 
Обращаясь со своей стороны к рассмотрению настоящего вопроса я лично пологаю, что отождествлять польское происхождение с принадлежностю к римской церкви едва-ли правильно. Во первых, в Западном крае есть обширная группа католического населения, которая не только не считает себя поляками, но находится с ними в антагонизме. Это литовско-жмудская народность, населяющая ковенскую губернию, численностю приблизительно около 1,5 миллионов. Литовцы с того времени, как среди них с особой силой начало появляться национальное самосознание, именно с середины 80-х годов настолько обесобились от поляков что стали требовать совершения у себя дополнительного богослужения не по польски а по литовски. На этой почве между литовцами а поляками происходили кровавые столкновения в костелах.

Против определения польского происхождения по признаку принадлежности к римской церкви, говорит и то соображение, что среди польяков имеется немало лютеран, а есть даже и православные. Так в 1902 г. Министерство в рапорте в Сенат признало лицом польского происхождения одного православного принесшего жалобу на отнесение его к числу лиц польского происхождения. Кроме того можно указать на наличность у нас общественных и государственных деятелей, которых нельзя не признать лицами русского происхождения несмотря на исповедывание ними католической религии. Я позволю себе привести один пример. Некто имя которого я потом назову. Родился в Вилне в католической семе и сам католик. Воспитывался в Виленской гимназии. После переехал в Петербург, поступил в одну из высших училищ, после в одну из академий. Кончил курс и был при ней профессором. Преподавал фортификацию Его Императорскому Величеству Государию Императору. Второй его специальностю была музыка, к которой у него имеется большой талант, при чем в течение свыше 40 лет он был музыкальным критиком, с фанатизмом отстаивая так называемую русскую музыку, перед коей он преклонялся и сам творил в духе новой русской школы. Вся жизнь его прошла в тесном общении с такими в полном смысле русским людми как покойный В. В. Стасов, трибун русского исскуства, русской старины Н. А. Римский-Корсаков, перелагавший на музыку наши былины, нашу мифологию Бородин, творец князя Игоря, Мусоргский, Балакирев. Я говорю об инжинере-генерале Ц. А. Кюи, которого иначе как русским общественным, государственным деятелем нельзя назвать.

По моему мнению польскую национальность следует определять по признаку употребления в домашнем быту польского языка. Затем не отрицая действительной связи между католиками и полонизмом в западном крае, я думал бы, что поляком следует считать того кто употребляет в домашнем быту польский язык и при этом исповедует римско-католическую веру. Конечно и это определение нельзя признать вполне исчерпывающим свой предмет - исключение, конечно, возможно. 


\section{A report of state counselor Strolman, head of the 7th division of the Department of General Affairs at the Ministry of Internal Affairs, on who should be con- sidered a "person of Polish origin".}

Russian State Historical Archive in Sankt Petersburg, collection 1278 (State Duma Chancellery), inventory unit 2, archive unit 1171 (On the application of zemstvo regulations of 12 June 1890 in the Vitebsk, Volhynia, Kiev, Minsk, Mogilev and Podolia guberniyas), fols. 101-103.

First of all, I consider it my duty to report that the Ministry of Internal Affairs does not possess extensive data in this matter. The reason for this deficiency is that penal laws used against persons of Polish origin were applied in practice by local authorities that had to decide in these issues on their own. It is true that the Ministry of Internal Affairs frequently received complaints from persons of this category that local authorities applied penal laws against them, but even in such case no need was felt to reflect on who should be considered as a "person of Polish origin". Thus, all legal provisions of this kind were based on discretionary (as explained by the Governing Senate) ${ }^{9}$ decisions of governors-general and this was a sufficient reason for the ministry not to discuss the essence of the matter, but report to the Governing Senate that the ordinance complained against was issued by local authorities based on their right of discretionary decision and as such its substance was not subject to examination by the Governing Senate.

The term "person of Polish origin" is related to the concept of penal rights and the areas of nationality and politics. As far as I am aware, it appeared for the first time in an ordinance on monetary reliefs, benefits and credits granted for the purchase of crown and private estates in western guberniyas, approved by the Tsar on 5 March $1864 .{ }^{10}$ Article 26 of the ordinance stressed that: "purchasers of estates who have been granted any reliefs, benefits or measures defined in this ordinance, as well as the heirs and successors to their rights, are prohibited from selling, pledging or otherwise transferring such estates to persons of Polish origin and Jews". Similar wording can be found in the instruction on rules of selling crown lands in western guberniyas to persons of Russian origin [emphasis in the original text] who work or intend to permanently settle there, approved by

9 The Governing Senate was established on 19 February 1711 as a higher state institution dealing with the activities of central administration bodies and legal regulations. During the times of Peter the Great, it was answerable to the Tsar only. From the early 19th century to 1864 it had the power to supervise the highest state institutions. Then, from 1864 to 1917, it acted as the highest cassation court in the Russian Empire.

10 Полное собрание законов Российской Империи (hereafter: ПСЗ), coll. 2, vol. 39 (1864), nos. 40655, 40656. 
the Tsar on 23 July $1865 .{ }^{11}$ Later this term can be found in the Tsar's decree of 10 December 1865 that prohibits persons of Polish origin for acquiring estates in the Western Krai in any manner except through hereditary succession. ${ }^{12}$ On the same day, the Tsar approved the minutes of a special commission, headed by the active privy counselor [Pavel] Gagarin, that was established to determine the means of settling Russian population in the Western Krai. The minutes, used as a basis for issuing the aforesaid decree of 10 December 1865, endeavour to give general guidelines on how to distinguish "persons of Polish origin". The minutes define "persons of Polish origin" not as the entirety of the Catholic population but only Poles and those native [emphasis in the original text] inhabitants of western lands who became Polish through assimilation. ${ }^{13}$ While such expression may seem imprecise in the legal aspect, in practice no doubts had so far been entertained when it was applied to persons. Among others, the definition did away with the issue of religious creeds, as it would be absolutely unjust to distinguish between owners on a religious instead of political basis.

An attempt to define the "person of Polish origin" term by the Minister of State Property is also known. In an explanation (no. 22) of 10 December 1869 addressed to the governor-general of the Northwestern Krai, the minister said: "Considering that the commission minutes approved by the Tsar on 10 December 1865 plainly indicate that the basis for distinguishing persons of Polish origin, who are prohibited from purchasing estates in the Western Krai, from persons of non-Polish origin, should be the nationality and not the creed of these persons, the Minister of State Property believes that conversion to the Orthodox faith by a person of Polish origin may not serve as a legal reason for not applying the regulations of 10 December 1865 to them. If descendants of these persons of Orthodox creed assimilate into the Russian nation over time, exactly like the ancestors of many of today's Polish landed gentry in the Western Krai who had been Russians once but have by degrees assimilated into the Polish nation once converted from the Orthodox to the Catholic faith, nevertheless an effective change of nationality requires considerable time and only when such has elapsed will those persons become essentially Russians and, definitely abandoning the Polish language, cease to be considered as persons of Polish origin. However, the actual change of nationality may not follow immediately and directly from the change of creed and, if effective regulations concerning persons of Polish origin were not applied to everyone who converted to the Orthodox faith, this would simply mean that the distinction between persons of Polish and non-Polish origin would not be based on nationality but on creed, an interpretation absolutely contrary to

11 ПС3, coll. 2, vol. XL (1865), no. 41957; vol. XLII (1867), no. 42328.

12 ПС3, coll. 2, vol. XL (1865), part 2, no. 42759, 42760.

13 RGIA, coll. 1263 (Комитет Министров), inventory unit 4, sec. 6, Журнал особой коммисси Высочайше утвержденной для рассмотрения Всеподданнейшаго доклада Министра государственных имуществ о мерах к водворению русского элемента в Западном крае. 
the spirit and literal meaning of the decree of 10 December 1865, which should be entirely protected against any changes and attempts to compromise its force".

Considering the above, persons of Polish origin, even if they had converted to Orthodoxy, cannot in any wise acquire crown lands under the Instruction of 23 July 1865 , because such estates are "sold to attract officials of Russian origin for service in western guberniyas and encourage them to continue their work there, and to support other loyal persons of Russian origin who wish to settle permanently in these areas". In subsequent years, until 1905, the matter was not revisited, all the more so since on 1 November 1896 the Tsar approved a confidential ordinance of the Council of Ministers that gave local authorities discretionary powers to issue or refuse certificates permitting the purchase of estates in the Western Krai by "persons of Russian and non-Russian origin. ${ }^{14 "}$

Later, an attempt to explain this term was made by the Committee of Ministers during a review of effective regulations concerning the limitations of rights of other nationalities and inhabitants of certain areas of the Empire with a view to carrying out point 7 of the personal decree of the Tsar of 12 December 1904 on measures for improvement of the state order, ${ }^{15}$ in which a review of such regulations was ordered, with the instruction to preserve from among them primarily those that protect the vital interests of the state and are beneficial to the Russian nation. On 1 May 1905 the Tsar approved the minutes of the Committee of Ministers concerning the manner of carrying out said point 7, which read: "Passing to the question of who can be granted such certificate (concerning qualification as a person of Polish origin), the Committee believes that, as the term 'Polish origin' is not precisely defined in law, it would be difficult to shift this burden on notaries drawing estate purchase deeds. Questions like these can be resolved solely by higher officials of local administration, specifically the governor-general and other governors, based on political and legal considerations of their nature. They are made more complex by the fact that the Catholic faith may be professed by persons of non-Polish origin whose right to purchase estates should not be limited. Only these officials have the means to ensure that the applicant is not a Pole

14 ПС3, coll. 3, vol. VI (1886), no. 3895.

15 Point 7 read as follows: “Произвести пересмотр действующих постановлений, ограничивающих право инородцев и уроженцев отдельных местностей Империи, с тем, чтобы из числа сих постановлений впредь сохранены были лишь те, которые вызываются насущными интересами Государства и явною пользою Русского Народа" ("Review existing regulations concerning the limitations of rights of other nationalities and inhabitants of certain areas of the Empire, with the provision to preserve from among them primarily those that protect the vital interests of the state and are beneficial for the Russian nation".) (Законодательные акты переходного времени. 1904-1908 г2. Сборник законов, манифестов, указов Пр. Сенату, рескриптов и положений комитета министров, относящихся к преобразованию государственного строя России, с приложением алфавитного предметного указателя, изд. 3-е, пересм. и доп. по 1 сентября 1908 года, ed. Н.И. Лазаревский, Санкт-Петербург 1909, pp. 3-6). 
or a Polonized Lithuanian, who is to be equated with Poles in this respect. The aforesaid local higher authorities should retain the right to bring complaints before courts to void any deeds based on illegal transactions". ${ }^{16}$

The Tsar's decree of 1 May 1905 abrogated the aforesaid regulation of 1 November 1886 and stripped higher local authorities of their discretionary powers to grant or refuse permits to purchase estates in the Western Krai. ${ }^{17}$ Consequently, a complaint against the ordinance of one of the governors that recognized the complainant as a person of Polish origin, now submitted to the Governing Senate on request of the ministry [probably the MIA] will be examined on the basis of substantive criteria. In matters of this kind, the ministry [probably the MIA] asked governors-general and governors of the Western Krai, relying on their experience with the realities of Borderland society, to provide information on who should be classified as a person of Polish origin. All opinions have been submitted but unfortunately they cannot be cited now as they are found at the Ministry of Finance to which they have been submitted by order of the Governing Senate to allow the Ministry of Finance to provide an opinion on the said complaint (the case involved a deposit for real estate in the Bank Szlachecki). It should be noted, however, that even these answers do not give a clear, accurate and complete picture of the term under consideration. Some opinions identify Polish origin with membership in the Roman Catholic Church: according to them, every Catholic is a Pole.

The following attempt to explain this problem made by one of the governors may be quoted: "A person of Polish origin is considered as someone who was born to Polish parents and is himself a Catholic. Conversion to Orthodoxy by him or his parents does not change his Polish nationality. Only when the applicant professes the Orthodox faith and is descended from parents born in that faith is there a sufficient reason for considering him a person of non-Polish origin".

To give my opinion on this question, I believe that equating Polish origin with membership in the Catholic Church does not seem to be warranted. First, in the Western Krai there is a large body of Catholics who do not only refuse to identify themselves as Poles but are also hostile to them. I mean here the approximately 1.5 million persons of Lithuanian and Samogitian nationality who live in the Kovno guberniya. In the 19th century, and especially after the mid-1880s, there was a powerful manifestation of national awareness among Lithuanians who started to distance themselves from Poles, demanding additional church services in their own tongue. This issue caused a number of bloody clashes between Poles and Lithuanians in churches.

16 “Извлечения из Высочайше утвержденного 1 мая 1905 года особого журнала комитета министров 15, 22 и 23 марта 1905 г. по делу о порядке выполнения пункта седьмого Именного указа 12 декабря 1904 года в отношении девяти западных губерний”, Право, 1905, nos. 1-26, p. 1575.

17 Законодательные акты переходного времени, pр. 51-53. 
Identification of Polish origin on the basis of Catholic Church membership is hindered also by the fact that not a few Poles profess the Lutheran faith, or even Orthodoxy. Thus, in 1902 the ministry [probably the MIA] in a report to the Senate considered as a person of Polish origin an Orthodox man who complained against being classified as such. Further, examples of social and national activists who cannot avoid being considered persons of Russian origin despite confessing the Catholic faith may be given. One of these examples I will take the liberty to cite. The man's name will be revealed later. He was born in Vilnius, in a Catholic family, and is a Catholic himself. Educated at the Vilna Gymnasium, he left for Petersburg, enrolled in one of the universities and then one of the academies. He graduated and became a professor there. He lectured on the art of fortifications to His Imperial Highness the Emperor. Besides, he was also a very talented musician and was a musical critic for more than forty years, an ardent defended of the so-called Russian music which he admired and composed himself following the style of the new Russian school. His whole life was spent in close association with Russian people in the full meaning of that word, for example Stasov, ${ }^{18}$ the tribune of Russian art and antiquities; Rimski-Korsakov ${ }^{19}$ who put our national sagas and myths into music; Borodin ${ }^{20}$ who wrote Price Igor, Mussorgsky ${ }^{21}$ and Balakiriev. ${ }^{22}$ I mean general engineer C.A. Cui ${ }^{23}$ who cannot be called otherwise than a Russian social and state activist.

My opinion is that Polish nationality should be defined on the basis of using the Polish language in everyday life. Besides, while not rejecting the actual relationship between Catholicism and Polonism in the Western Krai, I believe that Poles should be considered as those who use the Polish language in everyday life and additionally profess the Catholic faith. Obviously, even this definition does not completely exhaust the issue - exceptions are after all possible.

18 Vladimir Vasilievich Stasov (1824-1906), an eminent musical critic, art historian, archivist and social activist.

19 Nikolai Andreevich Rimski-Korsakov (1844-1908), composer, conductor and musical critic, author of, among others, 15 operas and 3 symphonies.

20 Aleksander Porfiryevich Borodin (1833-1887), composer, chemist and physician, wrote among others the Prince Igor opera.

${ }^{21}$ Modest Petrovich Mussorgsky (1838-1881), composer, wrote among others the Boris Godunov and Khovanshchina operas.

22 Mily Alexeevich Balakiriev (1837-1910), composer, pianist, conductor and educator.

${ }^{23}$ Cesar Antonovich Cui (1835-1918), composer, musical critic, general engineer, lecturer on the art of fortification. 


\title{
Is Every Pole a Catholic? - the Borderland Quandaries of Nationality and Religion Faced by Russian Bureaucracy in a 1910 Ministry of Internal Affairs Document
}

\begin{abstract}
During the long process of introduction of zemstva (organs of local government) to the Western guberniyas of Russia (began in 1906), there was once again the problem of domination of Polish landlords within the social structures as well as political and economic life of Belarusian and Ukrainian guberniyas. The tsarist authorities, who sought to ensure the dominance of a few Russian landowners in the electoral laws to zemstva, had to set up such an electoral system that would make it possible to reduce in zemstwa the number of Polish nobility. To do so, it was necessary to determine with precision who, according to laws, was "a person of Polish origin". Prime Minister Pyotr Stolypin, preparing the introduction of national curias for the elections to Western zemstva, ordered an official of the Ministry of Internal Affairs to work out a memorial describing all the methods used after the fall of the January Uprising to distinguish Polish landowners from all the members of this class. The memorial by Alexandr Strolman, presented here in its original form and in translation to the Polish language, is a historic review of all actions taken both by local and central authorities to establish basic criteria necessary to determine and distinguish all Polish landowner from among all the landowners in Western guberniyas of Russia.
\end{abstract}

\section{Каждый ли католик - поляк? Кресовые, национально-религиозные дилеммы российской бюрократии в документе Министерства Внутренних Дел 1910 года}

\section{Аннотация}

Во время длинного процесса введения земств в западных губерниях России (начатого в 1906 году) в очередной раз возникла проблема доминирования польских помещиков в общественных структурах, а также в политической и экономической жизни белорусских и украинских губерний. Власти, стремясь к обеспечению преимущества немногочисленным российским землевладельцам в земской избирательной системе, должны были создать такую систему, которая позволила бы сократить в ней число польских помещиков. Чтобы сделать это, надо было сначала точно определить, кто, в свете закона, считается «лицом польского происхождения». Премьер-министр Петр Столыпин, подготавливая введение национальных курий в выборах в западные земства, поручил чиновнику Министерства внутренних дел подготовить докладную записку, объясняющую, какими методами, в период после Январского восстания, государственные власти выделяли польских помещиков из всех представителей этой социальной группы. Докладная записка Александра Строльмана, напечатанная в подлиннике и в переводе на польский, является историческим обзором действий центральной и провинциальной администраций, направленных на определение основных критериев, отличающих поляков от всех остальных землевладельцев в западных губерниях России.

Перевод Агнешка Поспишиль 


\section{Bibliography}

\section{Archive material}

The Russian State Historic Archive in St. Petersburg (Российский государственный исторический архив), f. 1284 (Департамент общих дел МВД), f. 1263 (Комитет Министров)

\section{Published sources}

Полное собрание законов Российской Империи, Собрание 2, vol. 39 (1864).

Законодательные акты переходного времени. 1904-1908 гг. Сборник законов, манифестов, указов Пр. Сенату, рескриптов и положений комитета министров, относящихся $\kappa$ преобразованию государственного строя России, с приложением алфавитного предметного указателя, Изд. 3-е, пересм. и доп. по 1 сентября 1908 года, еd. Н.И. Лазаревский, Санкт-Петербург, 1909.

“Извлечения из Высочайше утвержденного 1 мая 1905 года особого журнала комитета министров 15, 22 и 23 марта 1905 г. по делу о порядке выполнения пункта седьмого Именного указа 12 декабря 1904 года в отношении девяти западных губерний”, Право, (1905), nos. 1-26.

\section{Secondary literature}

Bazylow L., Ostatnie lata Rosji carskiej. Rządy Stołypina, Warszawa, 1972.

Wieczorkiewicz P., "Stołypin, Polacy i ziemstwa zachodnie", in: Słowiańszczyzna i dzieje powszechne. Studia ofiarowane Profesorowi Ludwikowi Bazylowowi w siedemdziesiąta rocznice Jego urodzin, eds. L. Jaśkiewicz et al., Warszawa, 1985, pp. 125-153.

Базина Н.Г., "Возникновение национально-политической части Департамента общих дел Министерства внутренних дел”, Известия Российского государственного педагогического университета им. А. И. Гериена, 2006, no. 22, vol. 4, pp. 17-23.

Roman Jurkowski, professor in the Institute of History and International Relations of the University of Warmia and Mazury in Olsztyn (the head of the Eastern Europe Section). His research interests focus on the history of Polish landed gentry from the 'Stolen Lands', with special emphasis on the history of Polish political thought in those lands and the activities of Poles in the parliamentary life of the Russian Empire. The author of four monographs: Ziemiaństwo polskie Kresów Pólnocno-Wschodnich 1864-1904. Działalność społeczno-gospodarcza (2001); Sukcesy i porażki. Ziemiaństwo polskie Ziem Zabranych w wyborach do Dumy Państwowej i Rady Państwa 1906-1913 (2009); Successes and Failures. Polish Landowners from the Nine Western Provinces in the Elections to the Russian State Duma and State Council in the years 1906-1913 (2010); Kowieński marszałek, grodzieński gubernator. Kresowe poczatki kariery politycznej Piotra Stolypina (1889-1903) (2015). He also has published a comprehensive collection of source texts: Zanim przyszła „Pożoga”. Dokumenty i materiały dotyczace działalności polityczno-społecznej Polaków na Podolu w latach 1905-1910 (2011). He has authored over 140 articles, reviews, and source material publications in Polish, Russian, English and Lithuanian (roman.jurkowski@uwm.edu.pl). 